\title{
Assessment of anticardiolipin and antiphosphatidylserine antibodies in women with recurrent abortion
}

\author{
Ahmed J. Al-husynee \\ Department of Obestetric and Gynecology, Mosul Medical College.
}

(Ann. Coll. Med. Mosul 2008; 34(1): 54-57).

Received: $9^{\text {th }}$ Sept 2007; Accepted: $23^{\text {rd }}$ Apr 2008.

\section{ABSTRACT:}

Objective: To assess the prevalence of anticardiolipin (ACL) and antiphosphatidylserine (APS) antibodies in women with repeated abortion in Mosul region.

Methods: Women with history of three or more recurrent spontaneous abortions in their first trimester were studied, for ACL and APS antibodies in their sera by enzyme linked immunosorbent (ELISA). Fifty normal pregnant women during the first trimester were included as a control. Chi -squared test was utilized for evaluation.

Results: One hundred -sixty women were tested. ACL and APS were detected in 45/160 $(28 \%) \& 22 / 160(13.7 \%)$ respectively. These antibodies were negative in all control group.

Conclusion: Positivisty of ACL antibodies among women with recurrent spontaneous abortion is a common finding in Mosul region. The use of low dose aspirin plus heparin in management of such women had successful result.

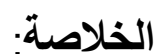
الهدف: معرفة مدى وجود مضاد الكارديوليبين (ACL) ومضاد الفوسفاتيدايل سيرين (APS) لادى النساء

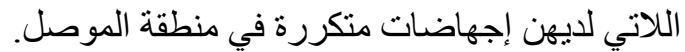
طرائق البحث: شملت الدراسة النساء الحوامل في الثلث الاول من الحمل ممن لديهن تاريخ ثلاثة اجهاضات تلقائية أو أكثر بإجر اء فحوص للتحري عن وجود اجسام مضادة لكل من ACL ، ACL في مصل الدم بطريقة كما شملت الدر اسة مجموعة سيطرة من (• ELISA قيمت النتائج بحساب مربع كاي (كمان

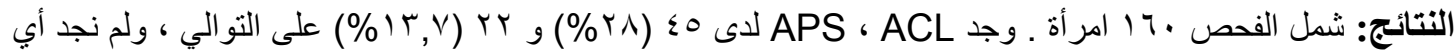
نتيجة ايجابية لأي الفحصين للجسمين المضادين APS ، ACL لدى النساء في مجمو عة السيطرة. الاستنتاج: ان ايجابية فحص ACL لدى النساء اللواتي لديهن تاريخ اجهاضات تلقائية متكررة كثيرة الحدوث في منطقة الموصل. وان استعمال الاسبيرين بجر عات يومية صغيرة مع الهيبارين في تدبير هذه الحالات يعطي نتائج طبية.
} 
$\mathbf{T}$ he aetiology of recurrent abortion is multifactorial. Patients with recurrent abortion after excluding ${ }^{(1)}$ anatomical, physiological and endocrine pathology and still had unexplained recurrent abortion not infrequently demonstrate other abnormalities including APS and ACL antibodies ${ }^{(2)}$. These antibodies are directed against anionic phospholipids or protein phospholipids complexes as in antiphospholipid syndrome (characterized by thrombosis, placental dysfunction, fetal death and the present of circulating antiphospholipid antibodies) ${ }^{(3)}$. History of recurrent pregnancy loss necessitating testing for antiphospholipid (APL) including (ACL and APS) antibodies ${ }^{(4)}$ Even with implantation failure by miscarriage, (APL) antibodies have been detected ${ }^{(5,6)}$.

The ACL antibodies positivity may be the most sensitive method in detecting and thus helping in preventing fetal loss ${ }^{(7,8)}$.

The aim of this report is to assess the status of such antibodies among women with recurrent abortion in Mosul.

\section{Patients and Methods:}

Women with history of three or more consecutive unexplained repeated abortion during the first trimester were included in the study.

Women were visitors of a private clinic. For all women, serum samples were tested for the presence of $A C L \lg G$ and APS IgG antibodies by ELISA technique in a private laboratory according to the principle of Harris et $\mathrm{al}^{(9)}$.
Fifty normal pregnant women during the first trimester were included as a control. The study extended from January 2003 until December 2006.

Both antibodies were tested twice with an interval of 5-6 weeks for each woman. Results of the tests were calculated against concentration, were interpreted in GPL units as $<15$ (negative), 15-19 (border line), $20-80$ as (positive) and $>80$ (high positive) .

Percentage calculation and Chi- square test were performed to find out the significance of $A C L$ and APS antibodies among the total ${ }^{(10)}$.

\section{Results :}

One - hundred - sixty women with unexplained recurrent spontaneous abortion were included. Their mean age was (28 years \pm 4$)$. Forty five $(28 \%)$ of these women had positive ACL IgG antibodies and were negative for APS antibodies. In the remaining 115 (negative ACL IgG antibodies) women, 22(19\%) were positive for APS antibodies. So both ACL and APS antibodies were found in $(41.8 \%)(67 / 160)$ of women with recurrent abortion.

Ninety three $(58.2 \%)$ women with repeated abortion were found to have a negative ACL and APS antibodies in their serum.

The ACL IgG antibodies were more significantly seen than APS IgG antibodies with $(P<0.001)$. There was no significant difference for both $\mathrm{ACL}$ and APS antibodies between positive and high 
positive cases. These antibodies were negative in all control cases.

Those cases with positive ACL IgG or APS IgG antibodies on one occasion, they received aspirin tablet $100 \mathrm{mg}$ daily until 36 weeks of pregnancy and those who are positive on two occasions, they received heparin 5000 IU two times daily subcutaneously up to 36 weeks of gestation. Such cases completed their pregnancy without complications and they had full term baby. Women with negative antibodies (ACL and APS) they did not received such therapy and we had a difficulty to follow them .

\section{Discussion:}

In our study we showed that $28 \%$ of women with recurrent abortion had a positive result for $A C L$. Our results were consistent with the other studies that 8$42 \%$ of recurrent abortion is due to $A C L$ antibodies. ${ }^{(11,12,13)}$ Also in this study our findings indicated that $(13.7 \%)$ of women with repeated abortion were positive for APS. The significant percentage of positive ACL has been noted in the sera of women who had repeated pregnancy loss of unknown etiology ${ }^{(14)}$.

It is important to note in this study that patients with negative $A C L$ antibodies had recurrent abortion in which 22/ (19\%) had positive APS antibodies. The IgG ACL was mentioned to be more significant than IgM in causing repeated abortion ${ }^{(15,16)}$.

In this study $67(41.8 \%)$ were considered to have antiphospholipid ( ACL and APs ) antibodies positive, comparable with other study; this finding was $74 \%^{(1)}$.

Antiphospholipid syndrome (APLs) is also presented with lupus anticoagulant. Although lupus anticoagulant and $A C L$ antibodies are present together in (APLs), these antibodies are not the same and many patients have one antibody only ${ }^{(17)}$.

Many studies discussed the role of antiphospholipid antibodies on the outcome of pregnancy, even in association with implantation failure as antiphosphatidylserine (APS) antibodies $^{(18)}$. So in this study we explained the significant role of APL antibodies such as ACL and APS in the occurrence of repeated abortions, especially with the successful outcome for our cases after they received the aspirine and the heparin therapy as mentioned by other ${ }^{(19,20)}$.

\section{References:}

1. Velay Utharp A., Archunan G. Evaluation of anticardiolipin antibodies and antiphosphatidylserine antibodies in women with recurrent abortion. Ind J. Of Med. Science. 2005; 59:347-352.

2. Ogasawra M, Aoki K, Yagami Y. Are ANA predictive recurrent miscarriage? Lancet 1996; 347:1183-4.

3. Sanjay C,Keswan B, Naresh C. Antiphospholipid syndrome. Jr Soc Med 2002;95:336-342

4. Rai R, Regan L: Obstetric complications of APL antibodies. Obstet Gynecol 1997; 9:387.

5. Coulam CB, Kaider B, Kaider A, et al APL antibodies associated with 
implantation failure after IVF/ET J Assist Reprod Genet 14:603,1997.

6. Birkenfeld A, Mukaida T, Minichiello L, et al. Incidence of autoimmune antibodies in failed embryo transfer cycles. AmJ Report Immunol .1994; 31:65-8.

7. Yetman D, Kutteh W. APL antibodies panel or recurrent pregnancy loss: Prevalence of ACL antibodies compared with other APLs antibodies, fertile 1996; 66:540-6.

8. Matzner $\mathrm{W}$, Chong $\mathrm{P}, \mathrm{Xu} \mathrm{G}$ et al . Charecterization of APLs antibodies in women with recurrent spontaneous abortion. J Reprod Med 1994; 39:27-30.

9. Harris EN, Gharavi AE, Patel S, et al. Evaluation of the $\mathrm{ACl}$ test : report of an international workshop held $4^{\text {th }}$ April 1986. Clin Exp Immunol 1987; 68:215-2.

10. Armitage $P(1987)$. Statestical methods in medical research. Second edition, Oxford Blackwell Scientific.

11. Kutteh W. Pasqurette $M$, Recurrent pregnancy loss. Adv obstet Gynecol 1995; 147-77.

12. Cowehack S, Smith, J. Gocial B. Antibodies to phospholipids and nuclear antigen in patients with repeated abortion , Am J Obstet Gynecol 1986; 155:1002-10.

13. Rai Rs. Antiphosphalipid syndrome and recurrent miscarriage. J Postgrad Med 2002;48:3-4.

14. Lockwood C, Romero R, Feinberg R et al. The prevalence and biological significance of lupus anticoagulant $\mathrm{ACL}$ antibodies in general obstetric population. Am J. Obstet Gynecol 1989; 161:369-73.

15. Lokshin M. APL Syndrome. Kelley's textbook of Rheumatology $5^{\text {th }}$; edition Philadelphia, WB Saunders: 2001;114552.

16. Kalra S, Tali A, Goyal U. et al Correlation of $A C L$ antibodies $\lg G$ with first trimester recurrent abortion. J Anat Soc. India 2002;51:10-3.

17. Pattision N, Chamley L, Liggins $\mathrm{G}$. et al . Antiphospholipid antibodies in pregnancy: prevalence \& clinical associations. Br J Obstet Gynecol, 1998, 100:909-13.

18. Matalons $\mathrm{S}$, Shoenfeld $\mathrm{Y}$, Blank M, et al Antiphosphatidylserine antibodies affect rat yolk sacs in culture in mechanism for fetal loss APL syndrome Am J Rerpod Immunol 2004; 51:144-51.

19. Triolo G, Ferrante A,Ciccia $F$. et al.Randomized study of subcutaneous low moleculer weight heparin plus aspirin in the treatment of recurrent fetal loss associated with antiphospholipid antibodies. Arthritis Rheum. 2003 Mar:48(3):728-731

20. Rai R, Regan L. Antiphospholipid antibodies in women undergoing invitro fertilization. Hum Reprod 1997:12:197-198 